7. D. Mermin, Phys. Rev. B 137, A1441 (1965).

8. D. Vanderbilt, Phys. Rev. B 41, 7892 (1990).

9. A. R. Oganov et al., J. Chem. Phys. 118, 10174 (2003)

10. B. B. Karki et al., Phys. Rev. B 55, 3465 (1997).

11. T. Tsuchiya et al., Geophys. Res. Lett. 31, L11610 (2004)

12. A. R. Oganov et al., Phys. Rev. B 71, 064104 (2005).

13. S. Ono et al., Earth Planet. Sci. Lett. 197, 187 (2002).

14. M. Murakami et al., Geophys. Res. Lett. 30, 1207 (2003)

15. Y. Kuwayama et al., Science 309, 923 (2005).

16. N. A. Dubrovinskaia et al., Phys. Rev. Lett. 87, 275501 (2001).

17. B. B. Karki et al., Science 286, 1705 (1999).

18. A. Navrotsky, Geophys. Res. Lett. 7, 709 (1980).

19. D. Valencia, R. J. O'Connell, D. Sasselov, Icarus, in press.

20. S. A. Weinstein, J. Geophys. Res. 100, 11719 (1995).

21. P. J. Tackley, J. Geophys. Res. 100, 15477 (1995).
22. P. B. Allen, V. Heine, J. Phys. C 9, 2305 (1976).

23. K. S. Song, R. T. Williams, Self-Trapped Excitons (Springer, Berlin, ed. 2, 1995), chap. 7

24. J. M. Ziman, Electrons and Phonons (Oxford Univ. Press, London, 1960).

25. F. ]. Blatt, Physics of Electronic Conduction in Solids (McGraw-Hill, New York, 1968).

26. R. S. Hixson et al., Phys. Rev. B 42, 6485 (1990).

27. G. A. Slack, in Solid State Physics, F. Seitz, D. Turnbull, Eds. (Academic Press, New York, 1980), vol. 34, pp. 1-71.

28. S. P. Clark Jr., Trans. Am. Geophys. U. 38, 931 (1957).

29. J. Parise et al., Eos Trans. AGU 85 (Fall Meet. Suppl.), abstr. MR23A-0188 (2004).

30. H.-Z. Liu et al., Geophys. Res. Lett. 32, L04304 (2005)

31. We thank D. Yuen, R. J. O'Connell, and D. Valencia for discussions and for sharing their unpublished results.
Research was supported by NSF grants EAR-0135533, EAR-0230319, and ITR-0428774/ITR-0426757 (Virtual Laboratory for Earth and Planetary Material, a NSF-funded project at the Minnesota Supercomputing Institute; www.vlab.msi.umn.edu).

\section{Supporting Online Material}

www.sciencemag.org/cgi/content/full/311/5763/983/DC1

Methods

SOM Text

Figs. S1 to S4

Tables S1 and S2

References and Notes

3 October 2005; accepted 30 December 2005

10.1126/science. 1120865

\title{
Changes in the Velocity Structure of the Greenland Ice Sheet
}

\section{Eric Rignot ${ }^{1 *}$ and Pannir Kanagaratnam ${ }^{2 *}$}

Using satellite radar interferometry observations of Greenland, we detected widespread glacier acceleration below $66^{\circ}$ north between 1996 and 2000, which rapidly expanded to $70^{\circ}$ north in 2005. Accelerated ice discharge in the west and particularly in the east doubled the ice sheet mass deficit in the last decade from 90 to 220 cubic kilometers per year. As more glaciers accelerate farther north, the contribution of Greenland to sea-level rise will continue to increase.

$\mathrm{T}$ he contribution of the Greenland Ice Sheet to sea level is a problem of considerable societal and scientific importance. Repeat-pass airborne laser altimetry measurements (1) showed that the ice sheet is nearly in balance in the interior but its periphery is thinning, with deterioration concentrated along the channels occupied by outlet glaciers (2). The most recent surveys revealed that the mass loss from the periphery is increasing with time, with approximately half of the increase caused by enhanced runoff and half by enhanced glacier flow (3).

Although these airborne surveys crisscrossed a large fraction of Greenland, they left major gaps in glacier coverage, particularly in the southeast and northwest. The mass loss from nonsurveyed glaciers was estimated using an ice melt model, thereby assuming no temporal changes in ice flow. If glacier dynamics is an important factor, the contribution to sea level from Greenland is underestimated using this approach. To address this issue and understand the exact partitioning between surface mass balance and ice dynamics, it is essential to estimate glacier discharge and its variability over time.

Here, we measure glacier velocities using satellite radar interferometry data collected by Radarsat-1 in fall $2000(4,5)$ along the entire coast of Greenland except the southwest (Fig.

\footnotetext{
${ }^{1}$ ]et Propulsion Laboratory, California Institute of Technology, Mail Stop 300-319, Pasadena, CA 91109-8099, USA. ${ }^{2}$ Center for Remote Sensing of Ice Sheets (CReSIS), University of Kansas, Lawrence, KS 66045, USA.

*To whom correspondence should be addressed. E-mail: eric.rignot@jpl.nasa.gov (E.R), pannir@ku.edu (P.K.)
}

1) and repeatedly in spring and summer 2005 along selected tracks covering major glaciers. We also use European Remote Sensing satellites ERS-1 and ERS-2 data from winter 1996 in the north, east, northwest, and central west, and Envisat Advanced Synthetic Aperture Radar (ASAR) data from summer 2004 in the southwest. Ice velocity is measured with a precision of 10 to $30 \mathrm{~m} /$ year depending on satellite, data quality, and processing and is combined with ice thickness to calculate ice discharge.

Ice thickness is estimated with a precision of $10 \mathrm{~m}$ from airborne radio echo sounding data collected in 1997 to 2005 (6). Although grounding-line thicknesses of glaciers extending into floating ice tongues in the north are well known, ice thickness is difficult to measure at the fronts of calving glaciers in other parts of Greenland where no floating ice tongues develop. Ice thickness is only known several $\mathrm{km}$ upstream of the ice fronts. Ice fluxes are thus calculated at these upstream flux gates with a precision of $4 \%$. Ice-front discharge is deduced from the upstream flux by subtracting a zero-anomaly surface mass balance (7) between the flux gate and the ice front. The correction is small (Table 1). Ice-front discharge is initially calculated for 1996 if data are available; otherwise, it is calculated for 2000 . Ice-front discharge in subsequent years is obtained by multiplying the reference discharge by the percentage velocity increase averaged at the ice front, with a precision reduced to $10 \%$ because ice thickness is assumed to be steady. This approach alleviates the lack of frontal thickness data, accounts for higher dynamic losses nearer to the ice fronts, but omits dynamic losses below flux gates in the referenceyear calculation. Mass loss for each glacier system is deduced from the ice-front discharge in excess of the zero-anomaly surface mass balance calculated for the entire drainage, with a precision of $14 \%$ (Table 1).

We examined the seasonal variability in flow speed of major glaciers in fall 2000. We found no velocity change from September to January at the $1 \%$ level over the 24 -day averaging period of Radarsat-1. On the Petermann Glacier (1 in Fig. 1), a continuous set of observations in 2004 reveals an $8 \%$ increase in the summer months compared to winter (Fig. 2A). A similar seasonality is detected on Nioghalvfjerdsbrae and all southeast Greenland glaciers and has been observed on Jakobshavn Isbrae (8) and Columbia Glacier, Alaska (9). Winter velocities are therefore only $2 \%$ lower than the annual means, and flow changes must exceed $8 \%$ to be significant. No seasonal correction is applied to our data to compensate for the fact that surface velocities may represent 97 to $99 \%$ of vertically integrated velocities at the flux gates.

A nearly comprehensive estimate of ice discharge around Greenland is obtained for year 2000, and partial coverage for 1996 and 2005. The results are used to detect changes in ice discharge around the periphery caused by ice dynamics alone and determine their impact on ice sheet mass balance, independent of temporal changes in surface mass balance, i.e., accumulation and melt.

Many changes in velocity are observed in the north, but they are of little consequence to total mass balance. Harald Moltke Glacier was surging in 2005 after a quiescent phase. Nearby Tracy and Heilprin glaciers accelerated $40 \%$ and $18 \%$ in 2000 to 2005 (Fig. 2L), but the corresponding mass loss is small. Petermann Glacier has been stable since 1996, and its mass balance remains slightly negative. Academy Glacier tripled its speed in 2005 (Fig. 2C), which is typical for northern Greenland surge-type glaciers; its mass balance averages zero over the last decade. Farther east, the mass losses from decelerating Nioghalvfjerdsbrae and accelerat- 
Fig. 1. Ice-velocity mosaic of the Greenland Ice Sheet assembled from year 2000 Radarsat-1 radar data, color coded on a logarithmic scale from $1 \mathrm{~m} /$ year (brown) to 3 $\mathrm{km} /$ year (purple), overlaid on a map of radar brightness from ERS-1/ Radarsat-1/Envisat. Drainage boundaries for flux gates in Table 1 are in red. Drainage boundaries with no flux estimates but discussed in the text are in blue. Numbers refer to drainage basins in Table 1.

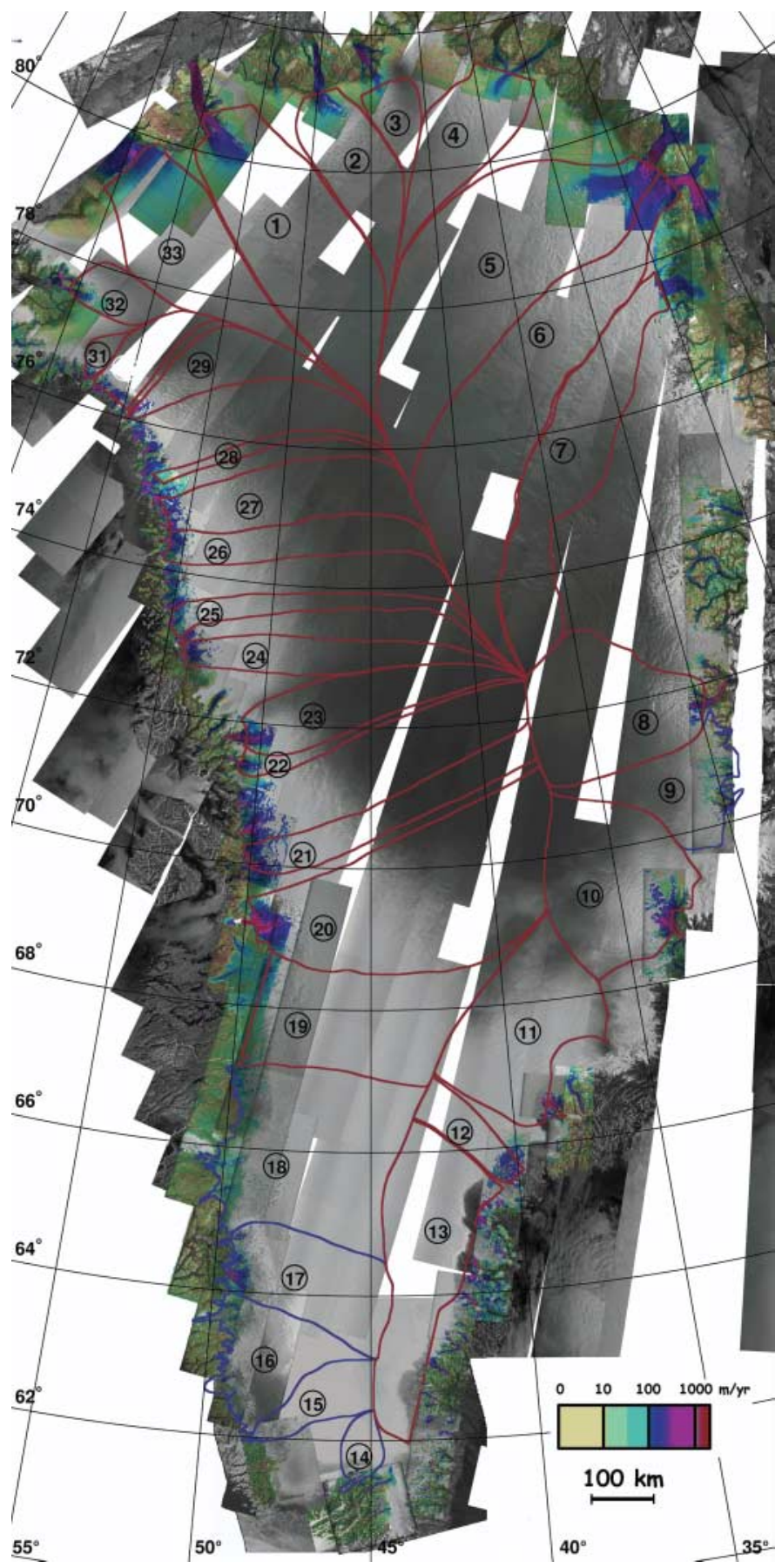

ing Zachariae Isstrøm compensate for the mass gain of decelerating Storstrømmen, a surge-type glacier in a quiescent mode (Fig. 2D). Overall, the northern sector exhibits a small mass loss (Table 1).

In central east Greenland, no flow change is detected on Daugaard-Jensen (Fig. 2E) and Vestfjord glaciers (area 9) in 1996 to 2005. The $3.7-\mathrm{km} /$ year frontal speed of DaugaardJensen is identical to that measured in 1969 (10), and the glacier is in balance. Immediately south, Kangerdlugssuaq Glacier has been stable in speed since 1962, but was thinning and losing mass in 1996 (11). The glacier accelerated $210 \%$ in 2000 to 2005 (Fig. 2F) to flow 13 to $14 \mathrm{~km} /$ year at the calving front, which is the largest speed in Greenland. The ice front retreated about $10 \mathrm{~km}$. The $8-\mathrm{km} /$ year additional frontal speed over the last $30 \mathrm{~km}$ must have longitudinally stretched the $1-\mathrm{km}$ thick ice to thin it by $250 \mathrm{~m}$. The acceleration increased the mass loss from $5 \mathrm{~km}^{3}$ ice/year in 1996 (12) to $36 \mathrm{~km}^{3}$ ice/year in 2005 (Table 1), which is $6 \%$ of Greenland's total accumulation.

Farther south, Helheim Glacier exhibited a positive mass budget in 1996 to 2004 (12) but was thinning at low elevation in the 1990s (2).
In 2000 to 2005 , the glacier accelerated $60 \%$ and retreated $5 \mathrm{~km}$ (Fig. 2G). The 6-km/year increment in speed over $40 \mathrm{~km}$ must have thinned the glacier by $75 \mathrm{~m}$. Its mass balance decreased from positive in 1996 to $-12 \mathrm{~km}^{3}$ ice/year in 2005, which is half the glacier annual accumulation.

Even more pronounced changes are taking place in the southeast, where most glaciers have no names (names in Fig. 2I are mostly associated with fjords) and are rarely visited. Snow accumulation is the highest in Greenland, causing high rates of ice discharge per unit area. This region was rapidly thinning up to the ice divide in the 1990s (1) and losing $17 \mathrm{~km}^{3}$ ice/year over $38,000 \mathrm{~km}^{2}$ in 1996 (12). Here, we estimate a $29-\mathrm{km}^{3} /$ year ice loss over a more comprehensive area of $73,700 \mathrm{~km}^{2}$ in 1996 (Table 1). The largest 21 glaciers accelerated $28.5 \%$ on average between 1996 and 2000 and $57 \%$ in 1996 to 2005 (Fig. 2I). Flow acceleration varies substantially among glaciers but remains widespread and systematic. Most glacier fronts retreated several $\mathrm{km}$ since 1996 . Total loss increased from $48 \mathrm{~km}^{3} /$ year in 2000 to $67 \mathrm{~km}^{3} /$ year in 2005, which is twice the 1996 value.

Few large glaciers drain the south and southwestern tips of Greenland because its ablation area is much broader and less steep than that in the southeast, so glacier ice discharge at the coast is low. Ice was thickening inland and thinning at low elevation in the 1990s (1). We have no thickness data and few velocity data for the largest glaciers. Nordbogletscher (area 14), Sermilik (area 15), and Kangiata nunata/ Narssap sermia (area 17) have, respectively, balance fluxes of only $1,6.5$, and $6 \mathrm{~km}^{3}$ ice/year, so potential mass losses from ice dynamics are small. Kangiata nunata sermia sped up by $6 \%$ in 1996 to 2000 and $27 \%$ in 2000 to 2005 , whereas Narssap sermia sped up by $68 \%$ and $150 \%$ (Fig. 2K). In areas 18 and 19, where ice flows only a few hundred meters per year, we detected a $25 \%$ acceleration in 2000 to 2005 (Fig. 2J). This region is unlikely to experience a positive mass balance at present.

Jakobshavn Isbrae underwent a 95\% increase in frontal speed in 1996 to 2005 during the progressive breakup of its floating ice tongue $(13,14)$ (Fig. 2H). In retreat since before the beginning of the century, the glacier was thickening in 1993 to 1998 (2) and then thinning (15). Its ice flux, deduced from radio echo sounding and seismic data (16), was 27 $\mathrm{km}^{3}$ ice/year in 1996. Ice discharge increased from $24 \mathrm{~km}^{3}$ ice/year in 1996 to $46 \mathrm{~km}^{3}$ ice/year in 2005 (Table 1).

Farther north, Kangilerngata and Eqip sermia accelerated by $30 \%$ in 2000 to 2005 , but the adjacent larger Sermeq avangnardleq and kujatdleq slowed down by $11 \%$ (Fig. 2M), so overall losses did not change. Rinks Isbrae (area 23) did not accelerate in 2000 to 2005 (Fig. 2N) but exhibits a negative mass balance. Similarly, Upernavik Isstrøm is $30 \%$ out of balance and 
Table 1. Mass loss of the Greenland Ice Sheet. A, area of drainage basin; F, ice flux upstream of ice front in 1996 (2000 if 6th column is blank); D, discharge ( $D=F-$ surface mass balance between gate and ice front); $S M B$, surface mass balance over entire drainage; $M B$, mass balance $(M B=$ $S M B-D)$. Missing values in 6th and 8th columns are replaced by 7 th column in totals. Loss of nonsurveyed west glaciers is extrapolated from average loss per unit area for areas 21 to 31 . Area 19 is for flux gate only. Total ice sheet mass balance, Total + SMB anomalies $=$ Total (ice dynamics for North + East + West $)+$ deviations in SMB from 1960 to 1990 average (19).

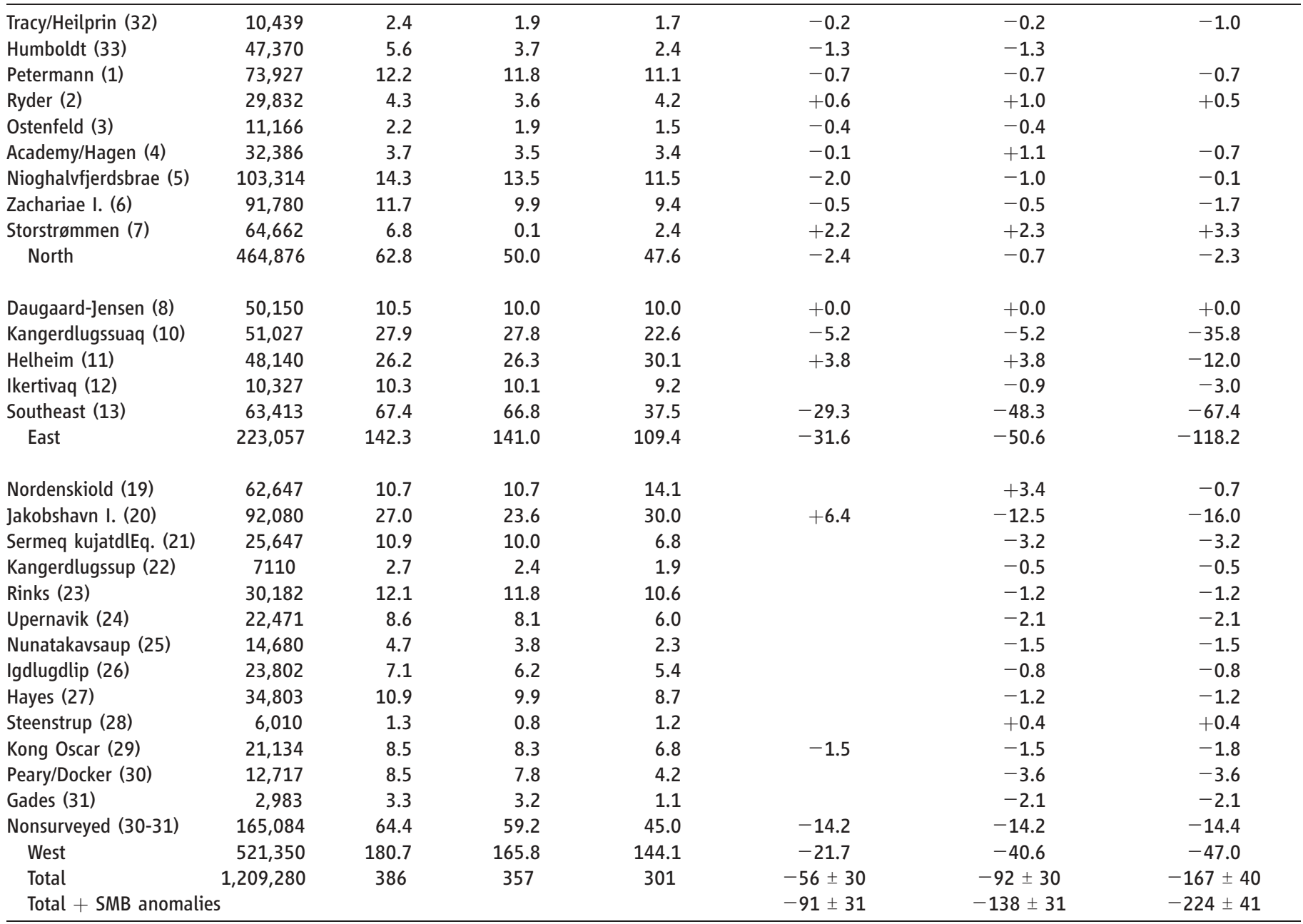

continues a retreat started early in this century (17). Mass balance is strongly negative as well for Igdlugdlip and Nunatakavsaup sermia, Steenstrup, Kong Oscar, Peary, Døcker Smith, and Gades glaciers, and probably all glaciers flowing from the high-accumulation northwestern belt. The fastest glacier, Kong Oscar, accelerated by $12 \%$ in 1996 to 2000 and none in 2000 to 2005 (Fig. 2O). Overall, flow acceleration north of $70^{\circ} \mathrm{N}$ is subdued or absent compared to that in the south. The largely negative mass balance of the northwest sector, however, which is consistent with its observed dynamic thinning $(1,2)$, suggests that the glaciers were already flowing above balance conditions in 1996. Comparison of the 2000 ice-front velocities with those measured in $1957 / 58$ to 1964 in areas 20 to $23(18)$ shows no detectable change in speed at the $10 \%$ level. If ice dynamics is the cause of thinning, glacier acceleration took place before 1957, and the year 2000 glacier losses have prevailed for many decades.

Glacier losses caused by ice dynamics alone are summarized in Table 1 for north, east, and west Greenland. The largest contributions are from southeast and northwest Greenland in 1996 to 2000 , with the addition of central east and west in 2000 to 2005 because of the acceleration of only three large glaciers. These estimates do not include glaciers draining from local ice caps, southwest Greenland glaciers, and small eastern glaciers south of Storstrømmen with low levels of ice discharge.

To obtain the total ice sheet loss, we need to combine the calculated losses from ice dynamics in Table 1 with deviations in surface mass balance from the long-term average calculated elsewhere. Climate warming in the last decade has enhanced surface melt and slightly increased snow precipitation to reduce the surface mass balance compared to the 1960 to 1990 average by an estimated $35 \mathrm{~km}^{3}$ ice/year in 1996 and 46 $\mathrm{km}^{3}$ ice/year in 2000 (19), which we linearly extrapolate to $57 \mathrm{~km}^{3}$ ice/year in 2005 . Total ice sheet loss, combining dynamic losses and deviations from a zero-anomaly surface mass balance, is then $91 \pm 31 \mathrm{~km}^{3}$ ice/year in 1996, $138 \pm 31$ $\mathrm{km}^{3}$ ice/year in 2000 , and $224 \pm 41 \mathrm{~km}^{3}$ ice/year in 2005 .

Greenland's mass loss therefore doubled in the last decade, well beyond error bounds. Its contribution to sea-level rise increased from $0.23 \pm 0.08 \mathrm{~mm} /$ year in 1996 to $0.57 \pm 0.1$ $\mathrm{mm} /$ year in 2005. Two-thirds of the loss is caused by ice dynamics; the rest is due to enhanced runoff minus accumulation. Ice dynamics therefore dominates the contribution to sea-level rise from the Greenland Ice Sheet.

Glacier acceleration in the east probably resulted from climate warming. Temperature records at Angmassalik $\left(65.6^{\circ} \mathrm{N}, 37.6^{\circ} \mathrm{E}\right)$ show a $+3^{\circ} \mathrm{C}$ increase in yearly air temperature from 
Fig. 2. Ice velocity (in meters per year) for 1996 (black), 2000 (blue), and 2005 (red) of Greenland glaciers versus distance. In (A) to (D) and (I) to (O), the selected velocity profiles cross the glaciers within a few $\mathrm{km}$ of the ice front, and distance is measured in a direction perpendicular to the glacier flow (west-east or north-south). In (E) to (H), the selected velocity profiles are in the alongflow direction, at the glacier center line, starting from above the flux gate (left side of the axis, negative distance) toward the ice front (right side of the axis, positive distance). (A) Petermann (1); (B) Ryder (2); (C) Academy/Hagenbrae (4); (D) Nioghalvfjerdsbrae/ Zachariae Isstrøm $(6,7)$; (E) Daugaard-Jensen (10); (F) Kangerdlugssuaq (11); (G) Helheim (12); (H) Jakobshavn Isbrae (20); (I) Southeast $(12,13)$; (j) Southwest (19); (K) Kangiata nunata/Narssap (17); (L) Tracy, Heilprin (32); (M) Sermeq kujatdleq (21); (N) Rinks Isbrae, Kangerdlugssup (22, 23); (0) Kong Oscar, Peary $(29,30)$. Arrows in (E) to $(\mathrm{H})$ indicate icefront positions on different years.
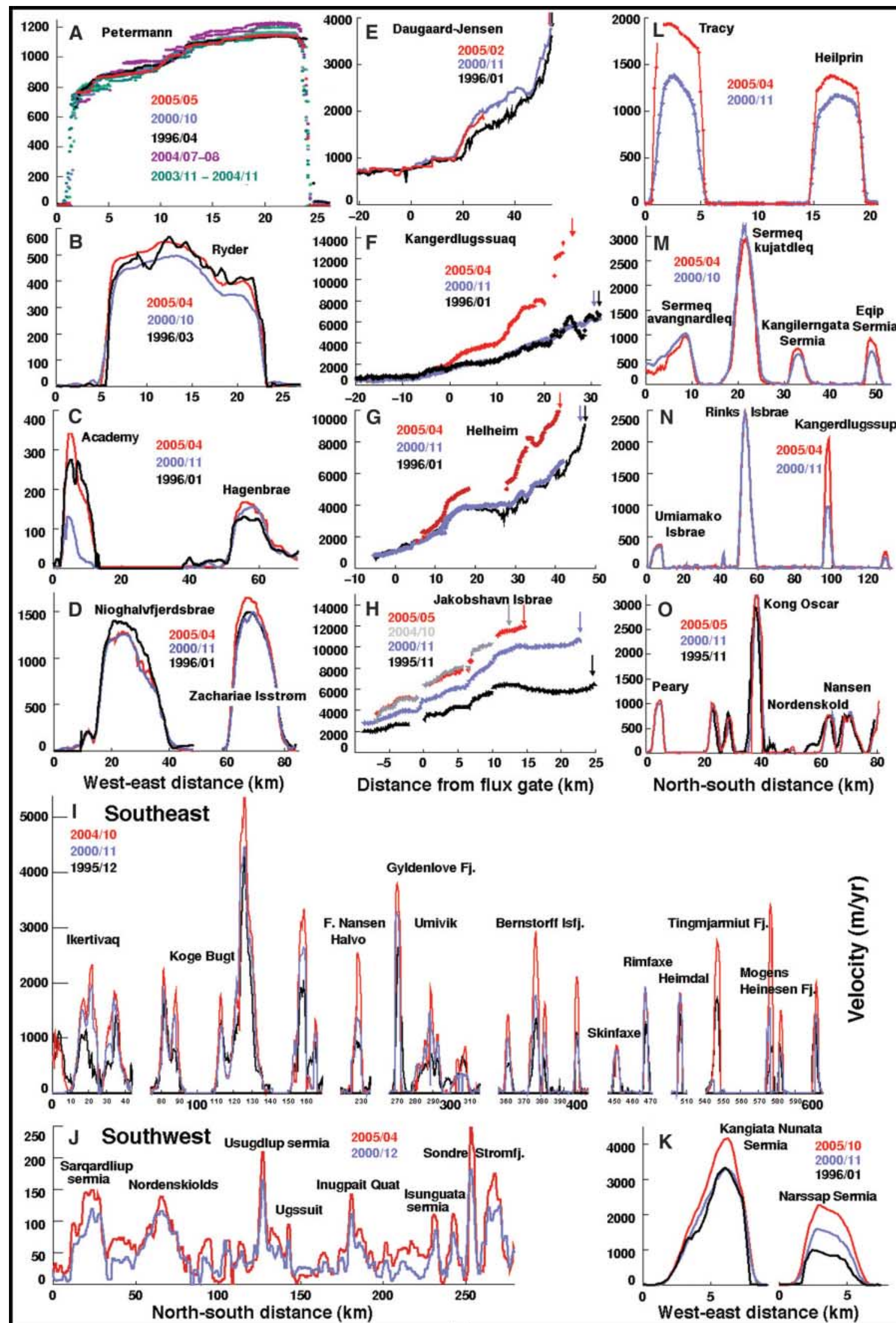
1981-1983 to 2003-2005. The processes that control the timing and magnitude of glacier changes are, however, not completely characterized and understood at present. Glacier accelerations have been related to enhanced surface meltwater production penetrating to the bed to lubricate its motion (20), and ice-shelf removal (13), ice-front retreat, and glacier ungrounding $(21,22)$ that reduce resistance to flow. The magnitude of the glacier response to changes in air temperature (surface melting) and ocean temperature (submarine melting at calving faces) also depends on the glacier-bed properties, geometry, and depth below sea level and the characteristics of the subglacial and englacial water-storage systems $(3,20)$. Current models used to project the contribution to sea level from the Greenland Ice Sheet in a changing climate do not include such physical processes and hence do not account for the effect of glacier dynamics. As such, they only provide lower limits to the potential contribution of Greenland to sea-level rise. If more glaciers accelerate farther north, especially along the west coast, the mass loss from Greenland will continue to increase well above predictions.

\section{References and Notes}

1. W. Krabill et al., Science 289, 428 (2000).

2. W. Abdalati et al., J. Geophys. Res. 106, 33279 (2001).

3. W. Krabill et al., Geophys. Res. Lett. 31, L24402 (2004).

4. The methodology used to map ice velocity has been developed in the 1990s with ERS-1/2 interferometric phase in north Greenland [e.g., $(5,23)]$, augmented with speckle tracking data from Radarsat- 1 in the 2000s (24) during the background mission of the second Antarctic mapping (25), which we also applied to 35-day repeat ERS-1 data.

5. E. Rignot, S. Gogineni, W. Krabill, S. Ekholm, Science 276, 934 (1997).

6. P. Gogineni, T. Chuah, C. Allen, K. Jezek, R. Moore et al., J. Glaciol. 44, 659 (1998).

7. Snow accumulation averaged for the period 1960 to 1990 is from (12). Surface melt is from a degree day model parameterized with 1960 s temperatures (23), which should represent average conditions in 1960 to 1990. These models yield $265 \pm 26 \mathrm{~km}^{3}$ ice/year runoff and $573 \pm$ $50 \mathrm{~km}^{3}$ ice/year accumulation for the $1.7-$ million- $\mathrm{km}^{2}$ ice sheet, consistent with published estimates.

8. A. Luckman, T. Murray, Geophys. Res. Lett. 32, L08501 (2005).

9. R. Krimmel, B. Vaughn, J. Geophys. Res. 92, 8961 (1987).

10. O. Olesen, N. Reeh, Grønlands Geologiske Undersogelse Rep. 21, 41 (1969).

11. R. Thomas et al., Geophys. Res. Lett. 27, 1291 (2000).

12. E. Rignot, D. Braaten, S. Gogineni, W. Krabill, J. McConnell, Geophys. Res. Lett. 31, L10401 (2004).

13. I. Joughin, W. Abdalati, M. Fahnestock, Nature 432, 608 (2004).
14. A. Weidick, N. Mikkelsen, C. Mayer, S. Podlech, Geol. Surv. Denm. Greenl. Bull. 4, 85 (2003).

15. R. Thomas et al., J. Glaciol. 49, 231 (2003).

16. T. Clarke, K. Echelmeyer, J. Glaciol. 42, 219 (1996).

17. A. Weidick in, Satellite Image Atlas of Glaciers of the World, U.S. Geol. Surv. Prof. Pap. 1386C, C1 (1995).

18. M. Carbonnell, A. Bauer, "Exploitation des couvertures photographiques aériennes répétées du front des glaciers vêlant dans Disko Bugt et Umanak Fjord, Juin-Juillet 1964" (Meddelelser om Grønland, Rep. 173, no. 5, 1968).

19. E. Hanna et al., J. Geophys. Res. 110, D13108 (2004).

20. H. J. Zwally et al., Science 297, 218 (2002).

21. R. Thomas, J. Glaciol. 50, 57 (2004).

22. I. Howat, I. Joughin, S. Tulaczyk, S. Gogineni, Geophys. Res. Lett. 32, L22502 (2005)

23. E. Rignot, W. Krabill, S. Gogineni, I. Joughin, J. Geophys. Res. 106, 34007 (2001)

24. R. Michel, E. Rignot, J. Glaciol. 45, 93 (1999).

25. K. Jezek, R. Carande, K. Farness, N. Labelle-Hamer, X. Wu, Radio Sci. 38, 8067 (2003)

26. We thank the numerous people involved with airborne campaigns in Greenland and two anonymous reviewers for their comments. This work was performed at the Jet Propulsion Laboratory, California Institute of Technology, and the University of Kansas, Lawrence, Kansas, under a contract with NASA's Cryospheric Science Program. Satellite radar data were provided by the European and Canadian Space Agencies and distributed by the Alaska Satellite Facility. The development of ice thickness was partially supported by the NSF under grant OPP-0122520 to the University of Kansas.

14 October 2005; accepted 17 January 2006 10.1126/science. 1121381

\section{Transitions to Asexuality Result in Excess Amino Acid Substitutions}

\author{
Susanne Paland and Michael Lynch
}

Theory predicts that linkage between genetic loci reduces the efficiency of purifying selection. Because of the permanent linkage of all heritable genetic material, asexual lineages may be exceptionally prone to deleterious-mutation accumulation in both nuclear and organelle genes. Here, we show that the ratio of the rate of amino acid to silent substitution $\left(K_{\mathrm{a}} / K_{\mathrm{s}}\right)$ in mitochondrial protein-coding genes is higher in obligately asexual lineages than in sexual lineages of the microcrustacean Daphnia pulex. Using a phylogeny-based approach to quantify the frequency of mutational-effect classes, we estimate that mitochondrial protein-coding genes in asexual lineages accumulate deleterious amino acid substitutions at four times the rate in sexual lineages. These results support the hypothesis that sexual reproduction plays a prominent role in reducing the mutational burden in populations.

A lthough sexual reproduction is costly when compared with asexual reproduction (1-3), it may accelerate the rate of adaptation and inhibit the accumulation of mildly deleterious mutations, because meiotic segregation and recombination facilitate the ability of natural selection to act independently on different genetic loci (2-6). These effects arise because the stochastic sampling variance associated with the interference between selection on linked loci reduces the genetic effective population size $\left(N_{e}\right)$, which increases the power of random genetic drift

Department of Biology, Indiana University, 1001 East 3rd Street, Bloomington, IN 47405, USA. E-mail: spaland@ indiana.edu (S.P.); milynch@indiana.edu (M.L.)
(7-9). As the frequency of recombination is reduced, the fates of mutant alleles become increasingly dependent on the backgrounds in which they originate, and the buildup of repulsion disequilibrium reduces the fitness differential between chromosomes (the HillRobertson effect) (7), thereby diminishing the efficiency of selection. As a consequence, mildly deleterious mutations may accumulate through several population-genetic mechanisms (10-15), leading to a long-term decline in fitness. Depending on the distribution of mutational effects, epistatic interactions between consecutive mutations can either slow or accelerate this process (16). Although increased rates of nonadaptive evolution have been documented for genomic regions with low levels of recombination and for nonrecombining chromosomes $(17,18)$, and it is thought that few asexual taxa persist for long periods of time (19), it remains to be determined whether mildly deleterious mutations play a critical role in their early demise (20).

To evaluate the degree to which sexual reproduction promotes the purging of deleterious mutations, we compared patterns of nucleotide substitution in the 13 protein-coding genes encoded by the mitochondrial genomes (supporting online text) of cyclically parthenogenetic ("sexual") Daphnia pulex with those in their obligately parthenogenetic ("asexual") derivatives (table S1). The latter represent independent lineages of recent origin resulting from a dominant sex-limited meiosis suppressor transmitted by male progeny of otherwise asexual lineages $(21,22)$. We reconstructed a phylogeny by application of a Bayesian method (23). Because this species is ancestrally sexual and reversals of asexuality to sexuality are unlikely (and unknown), asexual evolution is represented by sequence changes on branches connecting current asexuals with their most recent sexual ancestors. However, because asexuality may have actually arisen part way down a given asexual branch, the true differences between sexual and asexual sequence evolution reported below will be underestimated, making our test conservative.

The predicted molecular signature of deleterious-mutation accumulation for genes mostly subject to purifying selection $\left(K_{\mathrm{a}} / K_{\mathrm{s}}<1\right)$ is an increased rate of evolution at the amino acid level, whereas genes predominantly under 